Александр Дмитриевич Дуличенко Uniwersytet w Tartu aleksd@list.ru

\title{
Феномен славянских микрофилологий в современном славяноведении
}

Abstract: Duličenko Dmitrievič Aleksandr, Fenomen slavjanskih mikrofilologij v sovremennom slavjanovedenii (A Phenomenon of Modern Slavic Microphilology in Slavic Studies). „Poznańskie Studia Slawistyczne” 8. Poznań 2015. Publishing House of the Poznań Society for the Advancement of the Arts and Sciences, pp. 37-52. ISSN 2084-3011.

The article addresses a phenomenon of Slavic microphilology, outlines the structure and classification of modern Slavic literary microlanguages, introduces their different characteristic, and suggests arguments in favour of forming of Slavic microlinguistics and microphilology.

KeYwords: Slavic philology; prehistory of Slavic mikrolinguistics; literary microlanguages; mikrolinguistics, mikrophilologists

\section{1. Кое-что о предыстории}

Идея славянских микрофилологий стала развиваться с середины 60-х годов XX в. На начальном этапе интерес был проявлен к южнорусинскому (resp. русинскому, югославо-русинскому) микроязыку, о котором в те годы практически ничего не было известно. По крайней мере, в „большой славистике” об этом микроязыке в ту пору ничего нельзя было прочесть. Исключение составляли лишь небольшие статьи, публиковавшиеся в местной периодической печати и имевшие, таким образом, локальное распространение.

Может быть, имеет смысл кратко напомнить, как это все начиналось. Будучи еще студентом университета в г. Ашхабаде (Туркменская ССР, СССР), я много занимался различными славянскими и неславянскими языками, пока мои научные интересы не закрепились, помимо прочего, в области славистики. В ту пору республиканская и академическая библиотеки Ашхабада получали обязательный экземпляр всех книг, издававшихся в СССР на русском языке, немного 
хуже снабжалась университетская библиотека. Особенно заинтересовали меня языки тогдашней Югославии. Однажды загребский молодежный журнал „Plavi vjesnik” опубликовал мое объявление, в котором я выразил желание переписываться с молодежью этой страны, в том числе и на хорватско-сербском языке (5.08.1965, № 567). Среди множества откликнувшихся было и одно письмо от 9.08.1965 года из сербской Воеводины от Владимира Малацко из Руского Керестура, в котором он, среди прочего, написал:

Ја сам Русин, то јест југословенски Русин. И могу Ти рећи да је наш језик доста интересантан. За сада Ти могу рећи да је било 1947 године 200 година од како смо се населили у Југославији и то са Карпата из Украјине. Ми се налазимо између Суботице и Новог Сада у средњој Бачкој. Исто Ти могу рећи да је наш језик претежно још много задржао украјинског.

Установилась переписка. Меня очень заинтересовал язык, родной для Владимира. Приблизительно в ноябре он прислал мне номер газеты „Руске слово”, которая тогда издавалась в с. Руски Керестур - главном средоточии русин Югославии и которая до сих пор хранится в моем архиве (год издания XXI, № 39 за 24 сентября 1965 года, 8 страниц). До августа 1967 года он писал мне по-сербско-хорватски, а потом по моей просьбе перешел на родной южнорусинский язык. Несмотря на то, что он переехал в конце 1965 года в Савино Село, где женился на черногорке Дане и оттуда уже писал и присылал мне южнорусинские книги, в том числе и первую послевоенную школьную грамматику Мацеринска бешеда Миколы М. Кочиша (1965), наша переписка продолжалась до его преждевременной смерти: он прожил всего 41 год (1931-1972) и умер от излишней доли радиации, которую получил в армии.

В 1990 году я побывал в Савином Селе, где виделся с его супругой. Похоронен он был в Руском Керестуре, где я также бывал, но не смог, из-за напряженного графика, посетить его могилу... В моем архиве сохранилось 30 его писем, не считая книг и газеты „Руске слово", которую я получаю от редакции, ныне располагающейся в Новом Саде, уже почти полвека

В 1961-1966 годах, будучи студентом университета в Ашхабаде, я вместе со своими однокурсниками „издавал” журнал „Лингвист”. 
Этот журнал печатался на пишущей машинке (комплекты его хранятся в моем архиве). В номер 1 (7) за 1966 год была помещена моя небольшая заметка под названием $O$ диалекте русского языка в Югославии (л. 5).

В ту поре южнорусинский микроязык казался мне ,русским языком”. Вот содержание этой заметки:

Более двух веков назад на территории современной Югославии поселились несколько русских (скорее всего, украинских) семей. Затем приехало еще несколько десятков. Так возникли поселения выходцев из нашей страны в Югославии в районе мест Руски Крстур, Савино Село и других. Длительное проживание в окружении сербов и других этнических групп современной Югославии наложило отпечаток на язык поселенцев.

Появились формы, морфологически близкие к формам сербохорватского языка, сложились конструкции, типологически близкие сербским; и, конечно, происходил процесс заимствования лексики из сербохорватского языка (в основном лексика политического, общественного, специального и т.д. характера). Поселенцы считают свой язык „русским”, хотя и признают его основой украинский язык. В настоящее время носители этого диалекта двуязычны: кроме своего, они владеют и сербохорватским. Интересно отметить, что на этом диалекте в местах Руски Крстур и Нови Сад издаются книги (проза, поэзия, учебники, справочники и т.д.) и периодические издания (газета „Руске Слово”, журнал „Пионирска Заградка”). Кроме того, на „русском” языке ведется преподавание в школах. В конце 1965 года в городе Нови Сад выпущена грамматика: Микола М. Кочиш, Мацееринска бешеда, часц I, 1200 экз (Кочиш 1965).

В нашей лингвистической литературе не удалось найти ни одной работы или информации о данном диалекте. В январе 1966 года были написаны письма с просьбой о консультации известному знатоку современной Югославии Н.И. Толстому (Институт Славяноведения АН СССР), а также в редакцию газеты „Руске Слово” (Руски Крстур, Югославия).

Далее на страницах 8-9 этого же номера бюллетеня было опубликовано Письмо редактора „Руского слова” (Югославия), в котором, помимо прочего, было сказано: 
Мы считаем наш язык говором, называя его по-русински „бешеда”. Этим термином мы отделяем его от украинского языка, зная, что он его диалект, но, имея письменную форму, его можно считать отдельным языком в развитии. В истории он принял влияние польского, словацкого, венгерского и сербохорватского языков (л. 8).

\section{2. Контакт с академиком Никитой Ильичом Толстым и занятие южнорусинским микроязыком}

Как только установился контакт с Владимиром, я стал искать материал о югославо-русинском в наших библиотеках. К сожалению, в советское время ничего не было известно об этом микроязыке. Даже о русинском Западной Украины ничего не писалось - истории украинского литературного языка в этом аспекте данный регион практически не затрагивали. Тогда я обратился к крупнейшему в ту пору знатоку языков Югославии, позднее академику АН СССР/Российской АН Никите Ильичу Толстому. В конце 1965 года я написал ему письмо, в котором спросил, занимаются ли в СССР этой проблемой, можно ли считать южнорусинский отдельным славянским языком, существуют ли научные исследования по этому языку, на каком языке говорили переселенцы, когда они поселились в Югославии, и т.д. Надежды на ответ не было. Но неожиданно ответ пришел - через три месяца 30 марта 1966 года В нем, в частности, было написано:

Русинский язык - отдельный славянский литературный язык (микроязык). Если бы он не имел литературной обработки и на нем не выходила литература (учебники, книги, стихи, пресса), он был бы просто одним из славянских диалектов, диалектом переселенцев, каковыми являются, например, у нас болгарские или польские диалекты (на территории Белоруссии). В основе русинского литературного языка лежит диалект, но это уже не диалект, т.к. он обработан для литературного языка и имеет свою нормативную грамматику (...) Русинский диалект Руского Керестура [по происхождению] западноукраинский, а может быть, и восточнословацкий (поэтому Вам следует заняться и словацким языком!), или смешанный восточнословацкий-западноукраинский (а теперь еще и с сербским идет смешение). Случай очень интересный! Е. Паулини в своей Истории словацк[ого] лит [ературного] языка считал его словацким, другие украинским. А „русскими” они называют себя потому, что были униатами, т.е. не католиками.

Я побывал в Москве, встретился с Н.И. Толстым, захватив с собою тезисы своего доклада о взаимодействии южнорусинского 
с сербско-хорватским языком, который должен был прочитать на студенческой конференции университетов Средней Азии и Казахстана в г. Алма-Ате. Однако показать эта тезисы я так и не решился. Правда, вернувшись из Алма-Аты в Ашхабад, я вскоре выслал почтой тезисы уже прочитанного доклада и вскоре получил ответ (от 20 июня 1966 года). Среди прочего там было написано:

Я был рад получить от Вас письмо и книгу [первую часть школьного учебника Миколы М. Кочиша Мачеринска бешеда 1965 г. издания]. Грамматика - интересна, а доклад Ваш, вернее, его тезисы, совсем корректно и грамотно написаны и есть смысл продолжать работать над избранной темой. Подумав немного о Вашей теме, я пришел к выводу, что она могла бы стать диссертацией, если к ней подойти серьезно и продуманно. Вы, безусловно, правы, что „русинский язык” (будем его так пока условно называть) можно считать одним из славянских литературных [подчеркнуто!] (стандартных) языков, и то, что он распространен на очень небольшой территории и им пользуется очень малое число людей, существенно дела не меняет.

И далее:

Я очень рад нашему знакомству и надеюсь, что Вы, хотя и в отрыве от славистических центров, сумеете стать славистом. Помните, что все дается трудом, но это и есть в конечном итоге самое интересное в жизни. Трудитесь постоянно, куда бы Вас ни забросила судьба.

Так все и началось. В 1966 году я выступил на студенческой научной конференции в Ашхабаде с докладом Особенности развития некоторых грамматических форм языков Югославии в условиях языковых контактов (Дуличенко 1966 затем, мае 1966 года, на IX научной студенческой конференции университетов Средней Азии и Казахстана в Алма-Ате с докладом Проблема контактирования родственных языков. (Влияние сербохорватского языка на язык русин в Югославии). Это выступление окончательно убедило меня в том, что в дальнейшем нужно заниматься именно славянской филологией.

Я стал собирать материалы для кандидатской диссертации, но первые мои публикации по южнорусинскому языку появились в 1969 году, когда я работал некоторое время в Самаркандском университете. В 1972 году, уже установив хороший контакт с южнорусинами, я опубликовал у них в журнале „Шветлосц” первую статью, которая была переведена на южнорусинский, - о становлении 
орфографических норм молодого славянского литературного языка. В 1974 году в Институте славяноведения (и балканистики) АН СССР под руководством Н.И. Толстого я защитил кандидатскую диссертацию Литературный русинский язык Югославии. (Очерк фонетики и морфологии), в 1976 году переехал из Средней Азии в Эстонию, в Тартуский университет, где продолжил заниматься южнорусинским, другими проблемами славистики, славянской микролингвистики и общего языкознания.

\section{3. Занятие другими литературными микроязыками}

Еще в начале 70-х годов, помимо южнорусинского, я стал разыскивать „микроязыковые феномены” в других частях славянского мира. Оказалось, что южнорусинский микроязык - не единственный прецедент такого рода в этом мире. Постепенно мне стала раскрываться Микрославия - с 1976 года появляются мои публикации по градищанско-хорватскому, затем по другим микроязыкам. Результатом этих разысканий, связанных с увеличением числа микроязыков и их анализом, явилась докторская хабилитационная диссертация Славянские литературные микроязыки. (Вопросы формирования и развития), защищенная в 1981 году в Институте языкознания им. Я. Коласа Белорусской АН в г. Минске.

В этой диссертации, помимо южнорусинского, типологическому анализу продверглись также градищанско-хорватский, молизскославянский, чакавский и кайкавский, прекмурско-словенский, банатско-болгарский, кашубский, восточнословацкий, ляшский, карпаторусинский, резьянский.

Теоретическая часть диссертации отражена в нашей специальной монографии Славянские литературные микроязыки. (Вопросы формирования и развития) (1981). В дальнейшем в славянскую микролингвистику были вовлечены и другие микроязыки, среди которых серболужицкие - верхнелужицкий и нижнелужицкий, эгейско-македонский, помакский, венецианско-словенский, западнополесский, буневский, силезский, гуральский и др. Позднее нами был издан двухтомник образцов текстов на микроязыках - Славянские литературные 
микроязыки. Образиь текстов (2003-2004); во втором томе наших Основ славянской филологии специальная глава посвящена славянской микролингвистике (2011: 315-434).

\section{4. Славянская микролингвистика и микрофилология}

Так постепенно сформировался особый раздел славянской макролингвистики - славянская микролингвистика. Славянская микролингвистика является, в свою очередь, разделом славянской микрофилологии. Схематически соотношение макрофилологий и микрофилологий можно было бы представить следующим образом:

славянская макрофилология

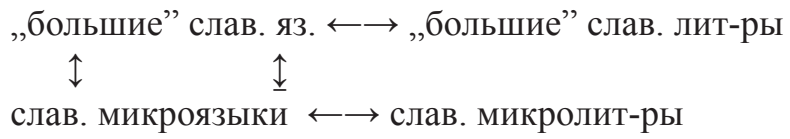

славянская микрофилология

При этом следует иметь в виду, что знак $\mathfrak{\imath}$ имеет условный характер: в одних случаях он указывает на генетическую связь с „большими” славянскими языками и с „большими” славянскими литературами (например, градищанско-хорватский, молизско-славянский, кайкавский, чакавский микроязыки - с хорватско-сербским/хорватским), в других непосредственной связи не наблюдается (например, верхне- и нижнелужицкие микроязыки).

Однако славянскую микрофилологию формируют далеко не все славянские микроязыки: некоторые из них вторую часть, т.е. славянскую микролитературу, имеют лишь в зачаточном состоянии, в других случаях основной акцент делается на лингвистической стороне вопроса и под. Но есть микроязыки, которые с успехом развивают обе стороны указанного процесса, т.е. это настоящие микрофилологии. 


\section{5. Классификация славянских литературных микроязыков и их проектов}

Прежде чем говорить о собственно славянских микрофилологиях, необходимо представить все славянские микроязыки, выделенные нами к настоящему времени. При этом следует иметь в виду, что предлагаемая классификация опирается на ареально-географический принцип в сочетании с этнолингвогенетическим и литературно-языковым. В соответствии с этим литературные микроязыки делятся на четыре группы - автономные, островные, периферийно-островные и периферийные (или региональные):

Таблица 1. Классификация и состав славянских литературных микроязыков

\begin{tabular}{|c|c|c|}
\hline Микроязыки & страна, регион / культурный центр & $\begin{array}{l}\text { статист. } \\
\text { данные }\end{array}$ \\
\hline \multicolumn{3}{|l|}{ І. Автономные } \\
\hline $\begin{array}{l}\text { верхнелужицкий/ } \\
\text { hornjoserbšcina }\end{array}$ & $\begin{array}{l}\text { Германия, земля Саксония, ист. обл. } \\
\text { Верхняя Лужица / Будышин, в.-луж. } \\
\text { Budyšin (нем. Bautzen) }\end{array}$ & 40 тыс. \\
\hline $\begin{array}{l}\text { нижнелужицкий/ } \\
\text { dolnoserbšćina }\end{array}$ & $\begin{array}{l}\text { Германия, земля Бранденбург, ист. обл. } \\
\text { Нижняя Лужица / Коттбус, н.-луж. } \\
\text { Chóśebuz (нем. Cottbus) }\end{array}$ & ок. 20 тыс. \\
\hline $\begin{array}{l}\text { кашубский/kaszëbsczi } \\
\text { jãzëk }\end{array}$ & $\begin{array}{l}\text { Польша, Гданьское воев., ист. обл. } \\
\text { Поморье Гданьское и вост. часть } \\
\text { Западного / Картузы, Гданьск, польск. } \\
\text { Kartuzy, Gdańsk }\end{array}$ & $\begin{array}{l}\text { от } 200-367 \\
\text { тыс. }\end{array}$ \\
\hline \multicolumn{3}{|l|}{ II. Островные } \\
\hline $\begin{array}{l}\text { югославо-русинский } \\
\text { (южнорусинский)/руски } \\
\text { язик }\end{array}$ & $\begin{array}{l}\text { Сербия - Автономная обл. } \\
\text { Воеводина,Хорватия / Руски Керестур } \\
\text { (серб. Руски Крстур), Нови Сад / Загреб } \\
\text { (хорв. Zagreb) }\end{array}$ & ок. 25 тыс. \\
\hline $\begin{array}{l}\text { градищанско-хорватский/ } \\
\text { gradišćanskohrvatski jezik }\end{array}$ & $\begin{array}{l}\text { Австрия, земля Бургенланд / } \\
\text { Эйзенштадт, град.-хорв. Željezno (нем. } \\
\text { Eisenstadt) }\end{array}$ & 35-45 тыс. \\
\hline $\begin{array}{l}\text { молизско-славянский/ po/ } \\
\text { na našu }\end{array}$ & $\begin{array}{l}\text { Италия, обл. Молизе, пров. Кампо-бассо } \\
\text { (итал. Molise, Campobasso) / - }\end{array}$ & $\begin{array}{l}\text { ок.4-4,5 тыс. } \\
\text { (?) }\end{array}$ \\
\hline $\begin{array}{l}\text { резьянский/rozajanski } \\
\text { jazek/langač }\end{array}$ & $\begin{array}{l}\text { Италия, пров. Венеция - Джулия (итал. } \\
\text { Venezia - Giulia), долина Резья }\end{array}$ & ок. 3 тыс. (?) \\
\hline
\end{tabular}




\begin{tabular}{|c|c|c|}
\hline $\begin{array}{l}\text { банатско-болгарский/ } \\
\text { banátsći-balgarsći jazić }\end{array}$ & $\begin{array}{l}\text { Румыния, ист. обл. Банат / (в XIX в. } \\
\text { Центр - Винга / Vinga) }\end{array}$ & 18-22 тыс. \\
\hline \multicolumn{3}{|c|}{ III. Периферийно-островные } \\
\hline $\begin{array}{l}\text { (карпато) русинский/ } \\
\text { русинськый язык }\end{array}$ & $\begin{array}{l}\text { Украина - Закарпатская обл. } \\
\text { (Подкарпатская Русь); Вост. Словакия } \\
\text { (Пряшевская Русь); Польша, Венгрия, } \\
\text { (Румыния); США и Канада / разные }\end{array}$ & $\begin{array}{l}\text { данные } \\
\text { противоречивы }\end{array}$ \\
\hline $\begin{array}{l}\text { эгейско-македонский/ } \\
\text { македонски език от Егеј }\end{array}$ & Греция, Эгейская Македония / - & $\begin{array}{l}\text { от } 110 \text { до } 160 \\
\text { тыс. }\end{array}$ \\
\hline $\begin{array}{l}\text { помакский/pomatskes } \\
\text { giezik }\end{array}$ & $\begin{array}{l}\text { Греция, номы Ксанти, Родопи, Эврос, } \\
\text { ист. Зап. Фракия /Комотини (?) }\end{array}$ & 36-39 тыс. \\
\hline $\begin{array}{l}\text { венецианско-словенский/ } \\
\text { beneškoslov(i)enskijezik }\end{array}$ & $\begin{array}{l}\text { Италия, обл. Фриули - Юлийская } \\
\text { Краина,Терская и Недижская долины / - }\end{array}$ & ок. 9 тыс. \\
\hline $\begin{array}{l}\text { буневский/буневачки } \\
\text { jeзик/bunjevački jezik }\end{array}$ & $\begin{array}{l}\text { Сербия (Воеводина), } \\
\text { приграничныерайоны Венгрии/Суботица }\end{array}$ & 20 тыс. (?) \\
\hline \multicolumn{3}{|c|}{ IV. Периферийные (региональные) } \\
\hline чакавский/čakavština & $\begin{array}{l}\text { Хорватия, Адриатическое побережье } \\
\text { и острова / Сплит, Риека, хорв. Split } \\
\text { и Rijeka (?) }\end{array}$ & - \\
\hline кайкавский/kajkavština & $\begin{array}{l}\text { Хорватия, северо-запад и средняя } \\
\text { часть / Загреб, Вараждин (хорв. Zagreb } \\
\text { и Varaždin (?) }\end{array}$ & - \\
\hline $\begin{array}{l}\text { прекмурско-словенский/ } \\
\text { prekmurščina }\end{array}$ & $\begin{array}{l}\text { Словения, обл. Прекмурье / Мурска Сo- } \\
\text { бота (словен. Murska Sobota) }\end{array}$ & - \\
\hline ляшский/laščina & $\begin{array}{l}\text { Чехия, Силезия / Фридек-Мистек (чеш. } \\
\text { Frýdek-Místek) }\end{array}$ & - \\
\hline $\begin{array}{l}\text { восточнословацкий/ } \\
\text { vichod(no)slovenska reč }\end{array}$ & Восточная Словакия / - & - \\
\hline $\begin{array}{l}\text { западнополесский/ } \\
\text { заходышно-поліська мова }\end{array}$ & Белоруссия (част. Украина) / Мінск (?) & - \\
\hline силезский/ślōnska godka & $\begin{array}{l}\text { Горная Силезия (Польша), на востоке } \\
\text { Чешская Силезия (между Остравой } \\
\text { и Тешином) }\end{array}$ & - \\
\hline
\end{tabular}

Как видно, в таблице отражено 20 литературных микроязыков, при этом приводятся оригинальные названия микроязыков, сведения о том, в какой стране или регионе они распространены, имеют ли культурный центр и каково количество говорящих (если такие 
сведения имеются). К 18 микроязыкам, отраженным в нашей книге Основы славянской филологии (2011, II: 322-323), теперь прибавлено еще два - буневский в Сербии и в прилегающих областях Венгрии, силезский в Польше, а также в Чехии (в указанной книге сведения об этих попытках микроязыках имеются, но там они еще не были внесены в классификационные рамки; 2011, II: 345-346). Не совсем пока ясна ситуация с попытками создания гуральского (подгальского) литературного микроязыка в Польше. Есть попытки создания литературных микроязыков и в некоторых других регионах Славии.

\section{6. Генетический аспект славянских литературных микроязыков}

Если говорить о чисто генетической основе указанных литературных микроязыков, то большинство из них оказываются в южнославянской группе, далее следует западнославянская, затем восточнославянская и, наконец, „спорный” южнорусинский стоит несколько особняком. Представим генетическую классификацию микроязыков с указанием на их место в ареально-географической классификации:

Таблица 2. Генетическая классификация славянских микроязыков

\begin{tabular}{|llll|}
\hline $\begin{array}{c}\text { языковые группы } \\
\text { и языки }\end{array}$ & \multicolumn{1}{c}{$\begin{array}{c}\text { литературные } \\
\text { микроязыки }\end{array}$} & $\begin{array}{c}\text { место в ареально- } \\
\text { географич. классификации }\end{array}$ \\
\hline І. Южснославянская группа & $\leftarrow$ периферийные \\
\hline хорватский & $\rightarrow$ чакавский & \\
& $\rightarrow$ кайкавский & градищанско-хорватский $\leftarrow$ островные \\
& $\rightarrow$ молизско-славянский & \\
\hline словенский & $\rightarrow$ прекмурско-словенский $\leftarrow$ периферийный \\
& $\rightarrow$ венецианско-словенский $\leftarrow$ периферийно-островной \\
& $\rightarrow$ резьянский & $\leftarrow$ островной \\
\hline болгарский & $\rightarrow$ банатско-болгарский & $\leftarrow$ островной \\
& $\rightarrow$ помакский (в Греции) & $\leftarrow$ периферийно-островной \\
\hline македонский & $\rightarrow$ эгейско-македонский & $\leftarrow$ периферийно-островной \\
\hline сербско-хорватский & $\rightarrow$ буневский & $\leftarrow$ периферийно-островной \\
\hline
\end{tabular}




\begin{tabular}{|lll|}
\hline II. Западнославянская группа & \\
\hline серболужицкий & $\rightarrow$ верхнелужицкий & $\leftarrow$ автономные \\
\hline кашубский & $\rightarrow$ нижнелужицкий & $\leftarrow$ автономный \\
\hline $\begin{array}{l}\text { чешский } \\
\text { (+ польский) }\end{array}$ & $\rightarrow$ ляшский & $\leftarrow$ периферийный \\
\hline словацкий & $\rightarrow$ восточнословацкий & $\leftarrow$ периферийный \\
\hline силезский & $\rightarrow$ польский & $\leftarrow$ периферийный \\
\hline III. Восточнославянская группа & (карпато) русинский & $\leftarrow$ периферийно-островной \\
\hline украинский & $\rightarrow$ западнополесский & $\leftarrow$ периферийный \\
\hline $\begin{array}{l}\text { белорусский/ } \\
\text { украинский }\end{array}$ & южнорусинский \\
\hline IV. Закарп.- украинский (переходный к вост.-словацкому) \\
\hline \multicolumn{2}{|c|}{} \\
\hline
\end{tabular}

Примечание: 1) единого взгляда на генезис серболужицкого нет: по мнению одних исследователей, у него один генетический источник, по мнению других - таких источника два (потому и верхнелужицкий и нижнелужицкий); 2) ляшский в целом относят к чешскому генетическому источнику, однако все же вернее относить его к переходному чешско-польскому диалектному поясу; 3) западнополесский отражает белорусско-украинские черты; 4) буневский относится к сербско-хорватскому источнику; 5) силезский относится к польскочешскому источнику.

Таким образом, повторимся, к южнославянским по происхождению относятся 11 микроязыков, к западнославянским - 6, к восточнославянским - 2 и один ,переходный”.

\section{7. От микроязыков к микрофилологиям}

Теперь остановимся на вопросе о том, какие из микроязыков образовали славянские микрофилологии, какие находятся на пути к этому, а какие функционируют однобоко, так и не развив вторую часть микрофилологии, т.е. славянские микролитературы. 
Таблица 3. Микроязыки и славянские микрофилологии

\begin{tabular}{|c|c|c|}
\hline микроязыки & страна & cmamyc \\
\hline \multicolumn{3}{|l|}{ І. Автономные } \\
\hline верхнелужицкий/hornjoserbšćina & Германия & микрофилология \\
\hline нижнелужицкий/dolnoserbšćina & Германия & микрофилология \\
\hline кашубский/kaszëbsczi jãzëk & Польша & микрофилология \\
\hline \multicolumn{3}{|l|}{ II. Островные } \\
\hline южнорусинский/руски язик & Сербия, Хорватия & микрофилология \\
\hline $\begin{array}{l}\text { градищанско-хорватский/ } \\
\text { gradišćanskohrvatskijezik }\end{array}$ & Австрия & микрофилология \\
\hline молизско-славянский/ po/na našu & Италия & слабо развивающийся \\
\hline резьянский/rozajanski jazek/langač & Италия & (микрофилология) \\
\hline $\begin{array}{l}\text { банатско-болгарский/ } \\
\text { banátsći-balgarsći jazić }\end{array}$ & Румыния & микрофилология \\
\hline \multicolumn{3}{|l|}{ III. Периферийно-островные } \\
\hline $\begin{array}{l}\text { (карпато)русинский/ } \\
\text { русинськыйязык }\end{array}$ & $\begin{array}{l}\text { Украина, Словакия, } \\
\text { Польша, Венгрия, (Румы- } \\
\text { ния), США и Канада }\end{array}$ & микрофилология \\
\hline $\begin{array}{l}\text { эгейско-македонский/македонски } \\
\text { език от Егеј }\end{array}$ & Греция & слабо развивающийся \\
\hline помакский/pomatskes giezik & Греция & слабо развивающийся \\
\hline $\begin{array}{l}\text { венецианско-словенский/ } \\
\text { beneškoslov(i)enski jezik }\end{array}$ & Италия & слабо развивающийся \\
\hline $\begin{array}{l}\text { буневский/буњевачки језик/ } \\
\text { bunjevački jezik }\end{array}$ & $\begin{array}{l}\text { Сербия, } \\
\text { приграничныерайоны } \\
\text { Венгрии }\end{array}$ & (микрофилология) \\
\hline \multicolumn{3}{|l|}{ IV. Периферийные (региональные) } \\
\hline чакавский/čakavština & Хорватия & (микрофилология) \\
\hline кайкавский/kajkavština & Хорватия & (микрофилология) \\
\hline $\begin{array}{l}\text { прекмурско-словенский/ } \\
\text { prekmurščina }\end{array}$ & Словения & слаборазвивающийся \\
\hline ляшский/laščina & Чехия & слаборазвивающийся \\
\hline $\begin{array}{l}\text { восточнословацкий/vichod(no) } \\
\text { slovenska reč }\end{array}$ & Словакия & слаборазвивающийся \\
\hline $\begin{array}{l}\text { западнополесский/ } \\
\text { заходышнополіська мова }\end{array}$ & $\begin{array}{l}\text { Белоруссия, (част. } \\
\text { Украина) }\end{array}$ & (микрофилология) \\
\hline силезский/ślōnska godka & Польша, Чехия & микрофилология \\
\hline
\end{tabular}


Совершенно очевидно, что по тем данным, что мы отразили в таблице номер 3, половина микроязыков, можно сказать, успешно идет по тому же пути, что и „большие” славянские литературные языки. То есть это микрофилологии с двумя сторонами - микроязыками и микролитературами.

Таковых оказалось 8: верхнелужицкий и нижнелужицкий, кашубский, южнорусинский, градищанско-хорватский, банатско-болгарский, карпаторусинский, силезский.

К ним добавляются еще 5 микроязыков - у них по-разному отражается наполняемость сфер использования: резьянский и буневский постепенно выравнивают обе стороны микрофилологий; современные чакавский и кайкавский прежде всего развивают свои литературы, хотя по ним появляются и работы лингвистического плана (в XIX веке, до эпохи национального Возрождения, оба эти микроязыка имели грамматики); что касается западнополесского, то этот микроязык в последние годы, в связи с переездом из Белорусии в Россию его инициатора, стал постепенно сдавать свои позиции.

Таким образом, 13 микроязыков из 20 имеют все шансы на дальнейшее развитие: все три автономные; из 5 островных - южнорусинский, градищанско-хорватский, банатско-болгарский, а также резьянский; из 5 периферийно-островных - (карпато)русинский, а также буневский; из 7 периферийных - силезский, чакавский и кайкавский, а также западнополесский.

Что касается оставшихся, названных нами слабо развивающимися, молизско-славянского, эгейско-македонского, помакского, венецианскословенского, прекмурско-словенского, ляшского и восточнословацкого, то здесь процесс развития идет очень медленно, односторонне, хотя их дальнейшая судьба зависит от того, найдутся ли инициаторы, которые возглавят соответствующие литературно-художественные процессы.

\section{8. Функциональный аспект славянских литературных микроязыков}

Если взять за основу разработанную нами Картину реального использования славянских литературных микроязыков (помещена во 
втором томе наших Основ славянской филологии, 2011, II: 343), то окажется, что сферы использования микроязыков сильно разнятся.

Наиболее успешно заполняют функциональный спектр автономные микроязыки, за исключением нижнелужицкого, который постепенно теряет многие сферы использования.

Из островных микроязыков функциональный спектр заполняет лишь южнорусинский микроязык, в то время как градищанско-хорватский делает это в меньшей мере, а банатско-болгарский выступает слабее этого последнего; резьянский находится в развитии, а молизско-славянский время от времени переживает застой.

Из периферийно-островных микроязыков лишь (карпато)русинский можно назвать преуспевающим, в то время как буневский пока лишь набирает скорость, а эгейско-македонский, помакский и венецианско-словенский функционируют слабо.

Наконец, группа периферийных (региональных) микроязыков характеризуется следующими чертами: успешно развивается силезский микроязык, несколько односторонне, с преимуществом литературно-художественной стороны, функционируют чакавский и кайкавский, а также западнополесский; слабо развиваются прекмурско-словенский и восточнословацкий, а также ляшский.

На примере южнорусинского микроязыка - микроязыка с наибольшим функциональным спектром покажем, каковы возможности и к чему стремятся литературные образования подобного плана. В соответствии с Картиной реального использования славянских литературных микроязыков, представленной во втором томе нашей монографии Основы славянской филологии (2011), южнорусинский микроязык ныне представлен в следующих сферах: 1) художественная литература: поэзия: +; рассказ: +; роман: +; 2) средства массовой информации: периодика: +; газеты: +; журналы: +; ежегодники: +; смешанные издания: +; радио: +; телевидение: +; 3) образование: школа: +; основная: +; средняя: +; гимназия: +; отдельные классы: +; все предметы: +; отдельные предметы: +; университет: +; 4) администрация (по выбору): +; 5) наука (гуманитарная): +; 6) религиозная жизнь: +; церковь: +; перевод Библии: +; 7) собственные учреждения: +; 8) любительский театр: +; 9) топографические надписи: +; 10) личная переписка: +. 
Представленные 10 сфер с их подразделениями - это максимальное функциональное употребление, которого добился один из литературных микроязыков - южнорусинский. Из микроязыков к нему приближается автономный верхнелужицкий, затем следует островной градищанско-хорватский, далее - периферийно-островной (карпато) русинский и т.д.

Таким образом, бо́льшая часть микроязыков из представленного списка $(8+5)$ имеют тенденцию к тому, чтобы быть подобными „большим” славянским литературным языкам, хотя очевидно, что для этого им не хватает ряда признаков, как то государственные границы, несамостоятельный для многих из них этнический фактор, слишком малые количественные параметры и др. Тем не менее рассмотренные здесь славянские микрофилологии вместе с пока слабо развивающимися прецедентами составляют органичный компонент современного славянского этно-языкового мира, что дает право рассматривать их в составе современной славянской филологии.

Современные славянские языки и соответствующие им литературы составляют славянскую филологию - это факт, который не подвергается сомнению, можно сказать, с XIX века В XX веке этот раздел славяноведения усложнился за счет так наз. славянских микрофилологий, основу которых составляют славянские микроязыки с соответствующими микролитературами. Носителей этих микроязыков немного - от полутора тысяч до полумиллиона человека.

Современная классификация выделяет их четыре группы:

1. автономные (верхне- и нижнелужицкие, кашубский),

2. островные (южнорусинский, градищанско-хорватский, банатско-болгарский, молизско-славянский, резьянский),

3. периферийно-островные (карпаторусинский, помакский, эгейско-македонский, венецианско-словенский, буневский),

4. периферийные (чакавский, кайкавский, прекмурско-словенский, ляшский, восточнословацкий, западнополесский, силезский) - всего 20 микроязыков или попыток к их созданию.

Важно подчеркнуть, что это не окончательный список микроязыков и попыток к их созданию. Ростки новых образований литературных микроязыков наблюдаются в разных частях современной Славии, что в дальнейшем может привести в увеличению их числа. 
Рассматривается генетический аспект микроязыков: сначала идут как наиболее многочисленные южнославянские микроязыки, затем западнославянские, потом следуют восточнославянские и спорный по происхождению южнорусинский. Что касается функционального аспекта славянских микроязыков, то рассматриваются все их группы - автономные, островные, периферийно=островные и, наконец, периферийные (или, по-другому, региональные).

На примере южнорусинского показывается, как литературный микроязык может достичь максимального функционального спектра. В докладе предпринимается попытка показать, что к существующим „классическим” филологиям присовокупляется еще целая группа микрофилологий, обогащая тем самым славянскую филологию, причем еще не все микроязыки „доросли” до создания собственных филологий. Так, на приводимых примерах видно, что 8 микроязыков по своим функциональным и кодификационным признакам приближаются к большим славянским литературным языкам, 5 микроязыков находятся на пути к признанию их „полными” микроязыками. Что касается остальных, то они находятся в стадии развития и могут через некоторое время „перешагнуть” границу, отделяющую их от настоящих литературных микроязыков. На примере большинства славянских литературных микроязыков видно, какими путями идет создание филологий вообще.

\section{Литература}

Дуличенко А.Д., 1966, Особенности развития некоторых грамматических форм языков Югославии в условиях языковых контактов, „Лингвист” № 2 (8), л. 1, Ашхабад.

Дуличенко А.Д., 1981, Славянские литературные микроязыки. (Bопросы формирования и развития, Тарту.

Дуличенко А.Д., 2003, Славянские литературные микроязыки. Образиы текстов, т. 1, Тарту.

Дуличенко А.Д., 2004, Славянские литературные микроязыки. Образиы текстов, т. 2, Тарту.

Дуличенко А.Д., 2011, Основы славянской филологии: Историко-этнографическая и этнолингвистическая проблематика, Opole.

Кочиш М.М., 1965, Мачеринска бешеда. Граматика за V и VI классу основней школи, Нови Сад. 